Prepared in cooperation with the DuPage County Stormwater Management Division

\title{
Flood-Inundation Maps for a 1.6-mile reach of Salt Creek, Wood Dale, Illinois
}

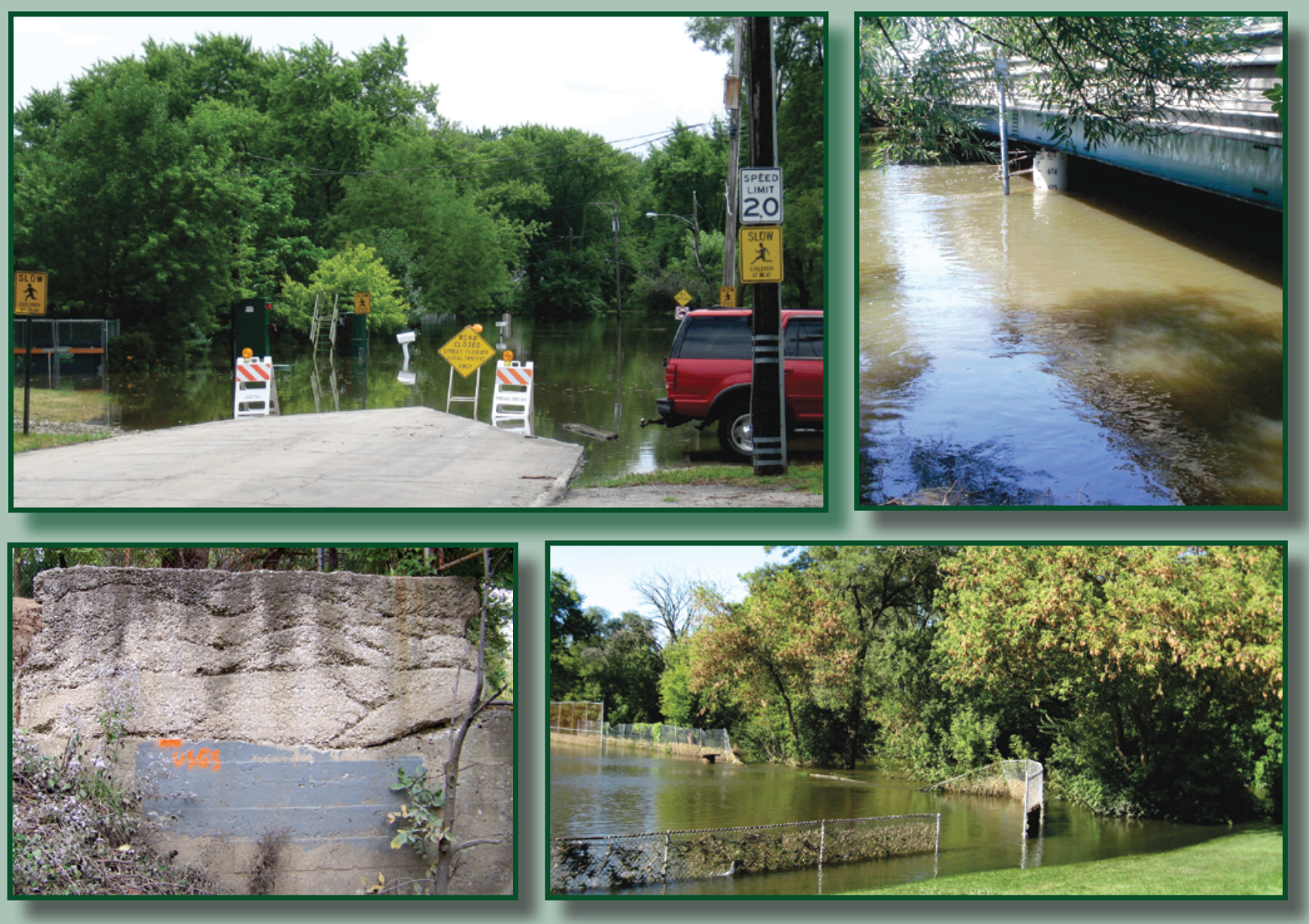

Pamphlet to accompany

Scientific Investigations Map 3185 
Cover. Photographs clockwise from upper left: Flooding on Edgebrook Road, downstream from the Wood Dale streamgage, taken July 2011, at a gage height of $14 \mathrm{ft}$; Irving Park Road bridge pier water-surface elevation reference, taken July 2011; High-water mark (HWM) photograph, taken in August 2010, during HWM collection following the July 2010 flood event; Flooding in floodplain downstream from the gage, taken Sept. 2008, at a gage height of $14.2 \mathrm{ft}$. 


\section{Flood-Inundation Maps for a 1.6-mile reach of Salt Creek, Wood Dale, Illinois}

By David T. Soong, Elizabeth A. Murphy, and Jennifer B. Sharpe

Prepared in cooperation with the DuPage County Stormwater

Management Division

Scientific Investigations Map 3185 


\section{U.S. Department of the Interior \\ KEN SALAZAR, Secretary \\ U.S. Geological Survey \\ Marcia K. McNutt, Director}

\section{U.S. Geological Survey, Reston, Virginia: 2012}

For more information on the USGS - the Federal source for science about the Earth, its natural and living resources, natural hazards, and the environment, visit http://www.usgs.gov or call 1-888-ASK-USGS.

For an overview of USGS information products, including maps, imagery, and publications, visit http://www.usgs.gov/pubprod

To order this and other USGS information products, visit http://store.usgs.gov

Any use of trade, product, or firm names is for descriptive purposes only and does not imply endorsement by the U.S. Government.

Although this report is in the public domain, permission must be secured from the individual copyright owners to reproduce any copyrighted materials contained within this report.

Suggested citation:

Soong, D.T., Murphy, E.A., and Sharpe, J.B., 2012, Flood-inundation maps for a 1.6-mile reach of Salt Creek, Wood Dale, Illinois: U.S. Geological Survey Scientific Investigations Map 3185, 8 p. pamphlet, 14 sheets, scale 1: 6,500. 


\section{Contents}

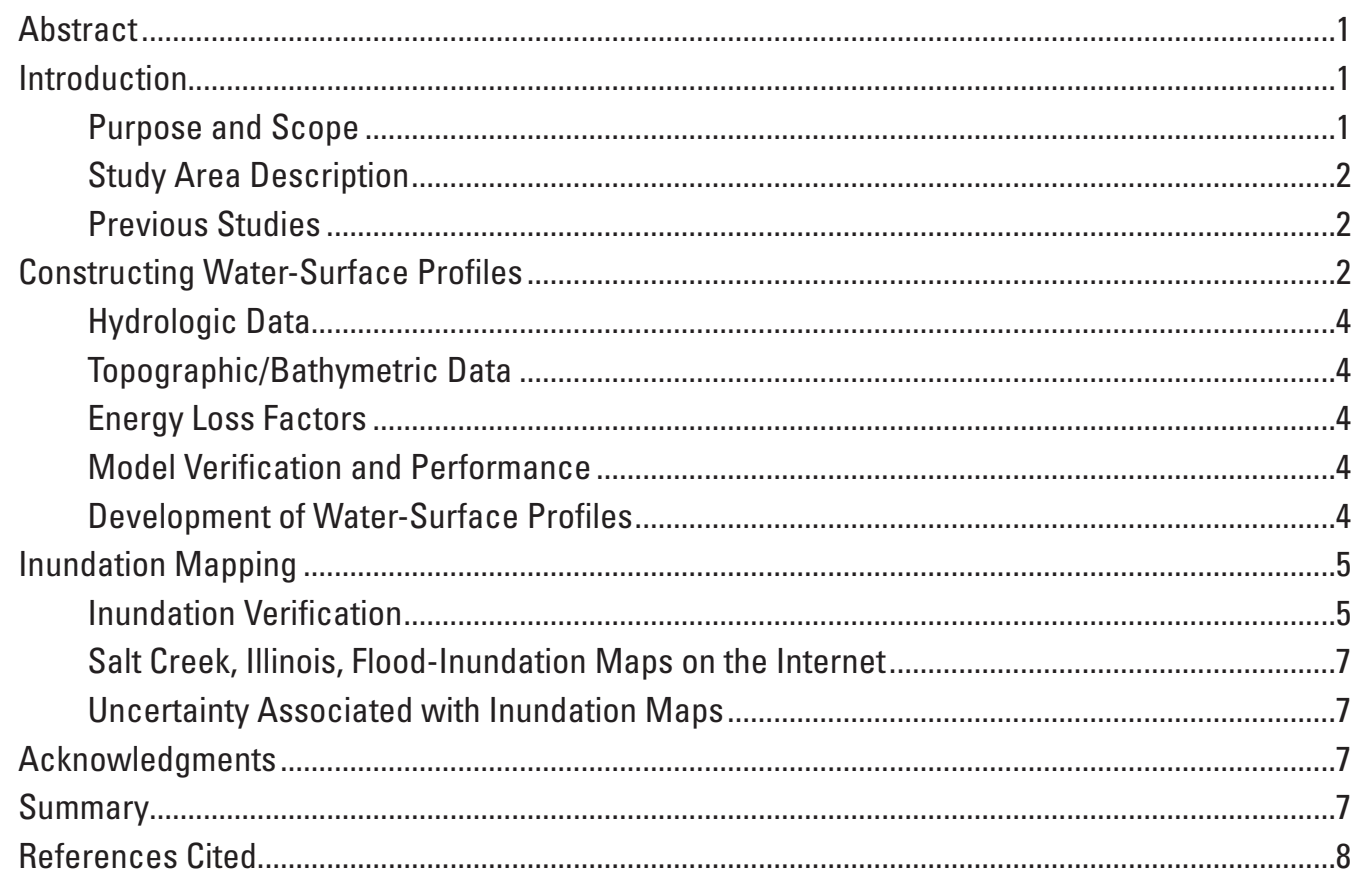

\section{Figures}

1. Map showing location of study reach for Salt Creek, Illinois, and location of USGS streamgage site

2. Graph showing stage-discharge relation generated by the FEO model for the September 2008 flood with historical discrete discharge measurements taken at the Salt Creek at Wood Dale streamgage..

3. Map showing high-water marks from the July 2010 flood plotted with the inundation surface for the 14-ft gage height at the Salt Creek at Wood Dale streamgage.

\section{Tables}

1. USGS streamgage and miscellaneous site information for study area, Salt Creek, Illinois.

2. 1.0 percent annual exceedance probability peak-discharge estimates and drainage areas for selected locations on Salt Creek near Wood Dale, Illinois. 


\section{Sheets}

Flood-inundation maps for a 1.6-mile reach of Salt Creek at Wood Dale, Illinois, corresponding to USGS Streamgage Salt Creek at Wood Dale (sta. no. 05531175) for gage height of:

1. 11 feet.

2. 11.5 feet.

3. 12 feet.

4. 12.5 feet.

5. 13 feet.

6. 13.5 feet.

7. 14 feet.

8. 14.5 feet.

9. 15 feet.

10. 15.5 feet.

11. 16 feet.

12. 16.5 feet.

13. 17 feet.

14. 17.5 feet. 


\section{Conversion Factors}

Inch/Pound to SI

\begin{tabular}{lcl}
\hline \multicolumn{1}{c}{ Multiply } & \multicolumn{1}{c}{ By } & \multicolumn{1}{c}{ To obtain } \\
\hline inch (in.) & \multicolumn{1}{c}{ Length } \\
foot (ft) & 25.4 & millimeter $(\mathrm{mm})$ \\
mile (mi) & 0.3048 & meter $(\mathrm{m})$ \\
& 1.609 & kilometer $(\mathrm{km})$ \\
\hline square foot $\left(\mathrm{ft}^{2}\right)$ & \multicolumn{1}{c}{ Area } & \\
square mile $\left(\mathrm{mi}^{2}\right)$ & 0.09290 & square meter $\left(\mathrm{m}^{2}\right)$ \\
\hline & 2.590 & square kilometer $\left(\mathrm{km}^{2}\right)$ \\
\hline cubic foot per second $\left(\mathrm{ft}^{3} / \mathrm{s}\right)$ & \multicolumn{1}{c}{ Flow rate } & \\
\hline & 0.02832 & cubic meter per second $\left(\mathrm{m}^{3} / \mathrm{s}\right)$ \\
\hline foot per mile $(\mathrm{ft} / \mathrm{mi})$ & Hydraulic gradient & \\
\hline
\end{tabular}

Vertical coordinate information is referenced to the North American Vertical Datum of 1988 (NAVD 88).

Horizontal coordinate information is referenced to the North American Datum of 1983 (NAD 83).

Elevation, as used in this report, refers to distance above the vertical datum. 



\title{
Flood-Inundation Maps for a 1.6-mile reach of Salt Creek, Wood Dale, Illinois
}

\author{
By David T. Soong, Elizabeth A. Murphy, and Jennifer B. Sharpe
}

\section{Abstract}

Digital flood-inundation maps for a 1.6-mile reach of Salt Creek from upstream of the Chicago, Milwaukee, St. Paul \& Pacific Railroad to Elizabeth Drive, Wood Dale, Illinois, were created by the U.S. Geological Survey (USGS) in cooperation with the DuPage County Stormwater Management Division. The inundation maps, which can be accessed through the USGS Flood Inundation Mapping Science Web site at http:// water.usgs.gov/osw/flood_inundation/depict estimates of the areal extent of flooding corresponding to selected water levels (gage heights) at the USGS streamgage on Salt Creek at Wood Dale, Illinois (station number 05531175). Current conditions at the USGS streamgage may be obtained on the Internet at http://waterdata.usgs.gov/usa/nwis/uv?05531175.

In this study, flood profiles were computed for the stream reach by means of a one-dimensional unsteady flow Full EQuations (FEQ) model. The unsteady flow model was verified by comparing the rating curve output for a September 2008 flood event to discharge measurements collected at the Salt Creek at Wood Dale gage. The hydraulic model was then used to determine 14 water-surface profiles for gage heights at 0.5-ft intervals referenced to the streamgage datum and ranging from less than bankfull to approximately the highest recorded water level at the streamgage. The simulated watersurface profiles were then combined with a Geographic Information System (GIS) Digital Elevation Model (DEM) (derived from Light Detection and Ranging (LiDAR) data) in order to delineate the area flooded at each water level. The areal extent of the inundation was verified with high-water marks from a flood in July 2010 with a peak gage height of $14.08 \mathrm{ft}$ recorded at the Salt Creek at Wood Dale gage.

The availability of these maps along with Internet information regarding current gage height from USGS streamgages provide emergency management personnel and residents with information that is critical for flood response activities such as evacuations and road closures as well as for post-flood recovery efforts.

\section{Introduction}

DuPage County is part of the Chicago, Illinois, metropolitan area with an estimated population of 932,541 in 2009 (U.S. Census Bureau, 2011). Portions of DuPage County have experienced severe flooding numerous times; most notably in August 1987, September 2008, and July 2010. Flood plains within DuPage County are highly urbanized and contain a mix of residential and commercial structures.

Prior to this study, DuPage County officials have relied on several information sources to make decisions on how to best alert the public about impending flooding, and to mitigate flood damages. DuPage County has developed updated hydrologic and hydraulic models that enable the County to provide flood warning to citizens and to operate flood control reservoirs (Price, 2011). The hydrologic and hydraulic models developed by the County are more recent than those developed for the Federal Emergency Management Agency (FEMA) Flood Insurance Study (FIS) for DuPage County, Illinois, and Incorporated Areas dated December 16, 2004 (FEMA, 2004). An additional source of information is the U.S. Geological Survey (USGS) streamgage Salt Creek at Wood Dale, Ill. (sta. no. 05531175), from which current or historical water levels (gage heights) can be obtained. Although USGS current gage height is particularly useful for residents in the immediate vicinity of a streamgage, it is of limited use to residents farther upstream or downstream because the water-surface elevation is not constant along the entire stream channel.

\section{Purpose and Scope}

The purpose of this report is to (1) describe the development of a series of estimated flood-inundation maps for a 1.6-mile reach of Salt Creek between just upstream of the Chicago, Milwaukee, St. Paul \& Pacific Railroad and Elizabeth Drive near Wood Dale, Illinois, and (2) provide users with a library of flood-inundation maps that correspond to water levels referenced to the water-surface elevation (gage heights) at the USGS streamgage on Salt Creek at Wood Dale, 
Illinois, ranging from below bankfull ( $11 \mathrm{ft})$ to the maximum observed water level at the streamgage $(17.5 \mathrm{ft})$. This report is a description of the maps and other flood information available on the USGS Flood Inundation Mapping Science Web site at http://water.usgs.gov/osw/flood_inundation/.

\section{Study Area Description}

Salt Creek is in northeast Illinois in the Central Lowland physiographic province. The drainage area is $74.7 \mathrm{mi}^{2}$ at the USGS Wood Dale streamgage (table 1; USGS, 2011) with a total drainage area of approximately $117 \mathrm{mi}^{2}$ in DuPage County (DuPage County Department of Economic Development and Planning, Division of Stormwater Management, 2011). The headwaters originate in Lake County, and the stream flows generally southward through DuPage County. The Salt Creek watershed is divided between Upper Salt Creek and Lower Salt Creek (fig.1). The Lower Salt Creek watershed begins north of the DuPage county border, flows through DuPage County and ends at the junction with the Des Plaines River. There are eight major tributaries to Lower Salt Creek that join the main stem as it flows through DuPage County (DuPage County Department of Economic Development and Planning, Division of Stormwater Management, 2011). The study reach is approximately 1.6 miles long (fig. 1), has an average top-of-bank channel width of about $80 \mathrm{ft}$ and an average channel slope of $2 \mathrm{ft} / \mathrm{mi}$ based on cross-section information in the FEQ model input file. The basin terrain is generally flat and has been under development with residential, commercial and industrial areas since 1950 and population has increased 600 percent between 1950 and 2002 (DuPage County Department of Economic Development and Planning, Division of Stormwater Management, 2011). The land use along the study reach is commercial north of Irving Park Road, residential through the middle section of the reach, and forest preserve land through the south part of the study reach (fig.1). The main channel within the study reach has a railroad and two major road crossings.

\section{Previous Studies}

The current FIS for DuPage County, Ill., and Incorporated Areas dated December 16, 2004 (FEMA, 2004) includes the Salt Creek Main Stem study completed by the Soil Conservation Service and the Illinois State Water Survey in 1978. However, since that time new models have been developed by the County to utilize unsteady flow techniques and update information on structures along Salt Creek. The new models are a Hydrological Simulation Program-FORTRAN (HSPF) hydrologic model to simulate flows, and a Full EQuations (FEQ) hydraulic model to route the flows (Price, 2011). Estimates of the peak discharges for the 1.0 percent annual exceedance probability (100-year) flood along the Salt Creek, as shown in table 2 for the study reach, were described in FEMA (2004).

\section{Constructing Water-Surface Profiles}

The water-surface profiles used to produce the 14 floodinundation maps for this study were computed by using FEQ, version 10.61 (Franz and Melching, 1997a). FEQ is a onedimensional unsteady flow model for simulation of watersurface profiles. The FEQ model input file generally contains information about the stream hydrograph, the hydraulic properties of the floodplain and structures, the connectivity of stream cross-sections and structures, boundary conditions, initial conditions, and nodes storing water-surface elevations or hydrograph information (Franz and Melching, 1997a). The FEQ model was used to model Salt Creek because it is designed to be flexible and capable of modeling the complexity of the various control structures in this highly urbanized watershed. The FEQ model used to construct the water-surface profiles for this study reach was extracted from the larger FEQ model used to simulate the entire Salt Creek reach (Christopher B. Burke Engineering, 2010). The model was shortened from the original model to allow more certainty at the boundary conditions.

Table 1. USGS streamgage and site information for study area, Salt Creek, Illinois.

\begin{tabular}{ccccccc}
{$\left[\mathrm{mi}^{2}\right.$, square mile; $\mathrm{ft}$, feet $]$} & & & & \\
\hline Station name & Station number & Drainage area $\left(\mathrm{mi}^{2}\right)$ & Latitude & Longitude & $\begin{array}{c}\text { Maximum recorded } \\
\text { elevation at gage }\end{array}$ \\
\hline $\begin{array}{c}\text { Salt Creek at } \\
\text { Wood Dale }\end{array}$ & 05531175 & 74.7 & $41^{\circ} 57^{\prime} 50^{\prime \prime}$ & $87^{\circ} 59^{\prime} 02^{\prime \prime}$ & $\begin{array}{c}\text { Oct. 1999 to } \\
\text { current year }\end{array}$ & $\begin{array}{c}16.58 \mathrm{ft} \\
\text { (ft above NAVD 88) and date }\end{array}$ \\
\hline
\end{tabular}



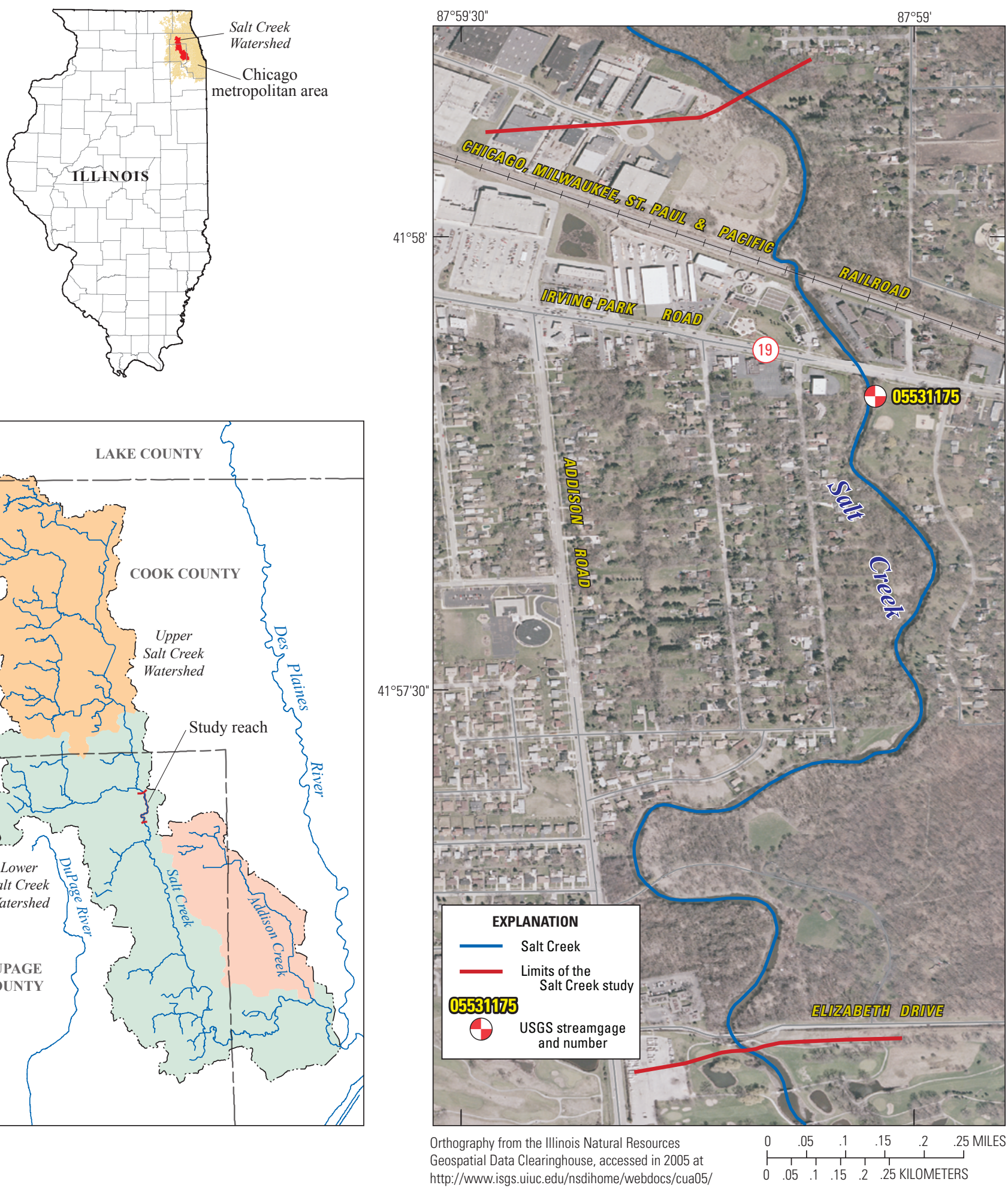

Figure 1. Map showing location of study reach for Salt Creek, Illinois, and location of USGS streamgage site. 
Table 2. 1.0 percent annual exceedance probability peak-discharge estimates and drainage areas for selected locations on Salt Creek near Wood Dale, Illinois (from FEMA, 2004).

$\left[\mathrm{mi}^{2}\right.$, square miles; $\mathrm{ft}^{3} / \mathrm{s}$, cubic feet per second; $\mathrm{ft}$, feet $]$

\begin{tabular}{lcc}
\hline \multicolumn{1}{c}{ Location on Salt Creek } & $\begin{array}{c}\text { Drainage area } \\
\left(\mathbf{m i}^{\mathbf{2}}\right)\end{array}$ & $\begin{array}{c}\text { Discharge estimate } \\
\left(\mathbf{f t}^{\mathbf{3}} \mathbf{s} \mathbf{s}\right)\end{array}$ \\
\hline Approximately $660 \mathrm{ft}$ upstream of Elizabeth Drive & 73.0 & 3,524 \\
Approximately $527 \mathrm{ft}$ downstream of Irving Park Road & 71.4 & 3,502 \\
$\begin{array}{l}\text { Approximately } 792 \mathrm{ft} \text { upstream from Chicago, } \\
\text { Milwaukee, St. Paul \& Pacific Railroad }\end{array}$ & 70.9 & 3,484 \\
\hline
\end{tabular}

\section{Hydrologic Data}

The study area hydrologic network consists of one streamgage (fig. 1; table 1). This gage was installed in October 1999 and has been measuring water levels (gage heights) continuously since installation. All water-surface elevations are referenced to North American Vertical Datum of 1988 (NAVD 88). In addition, some discrete discharge measurements were made at this site during periods of moderate to high flow and were used for model verification. High-water marks documented by the USGS following flooding in July 2010 were also used for verification of mapping extent.

A normal depth boundary condition was assumed downstream (with a friction slope estimated from the average streambed slope through the reach) at Interstate 290, approximately 1.1 miles downstream from Elizabeth Drive.

\section{Topographic/Bathymetric Data}

The digital elevation model data were derived from a $3-\mathrm{ft}$ horizontal resolution LiDAR dataset with a vertical accuracy sufficient to produce 1-foot contours. The LiDAR data were obtained from DuPage County (John McLaughlin, DuPage County Stormwater Management Division, written commun., 2009). The surveying for the study reach was done by Mackie Consultants, LLC. in 2003 and processed for the FEQ model using an ArcInfo (ESRI, 1999b) script program developed by DuPage County GIS staff (Christopher B. Burke Engineering, Ltd, 2010). Because the FEQ model was updated in 2010 for DuPage County by Christopher B. Burke Engineering, Ltd., the USGS did not update or do any additional field verification of the geometry in the FEQ model.

\section{Energy Loss Factors}

Field observations and high-resolution aerial photographs were used to select initial (pre-calibration) Manning's roughness coefficients (" $n$ " values) for energy (friction) loss calculations. The final Manning's $n$ values used ranged from 0.06 to 0.065 for the main channel and 0.085 to 0.2 for the overbank areas modeled in this analysis. The main channel bed is mostly sand, gravel, and silt and the overbank areas are vegetated with some areas having shrub and tree cover.
As described in the FEQ model documentation prepared by Christopher B. Burke Engineering, Ltd. (2010), the energy losses at bridge crossings were modeled with a computer model for Water-Surface PROfile computations (WSPRO) (Shearman, 1990) and Full EQuations UTilLties (FEQUTL) commands (Franz and Melching, 1997b).

\section{Model Verification and Performance}

The FEQ model was run in unsteady mode for the event of September 12-21, 2008, with flows ranging from $71 \mathrm{ft}^{3} / \mathrm{s}$ to $3,876 \mathrm{ft}^{3} / \mathrm{s}$. The simulated discharge hydrograph from the observed stage (gage height) hydrograph data at the Wood Dale gage was then input at the upstream end of the reach (near the Chicago, Milwaukee, St. Paul \& Pacific Railroad). The unsteady FEQ model output was used to create a stagedischarge relation at the gage that was compared to discrete discharge measurements taken at various times throughout the gage history (fig. 2).

Because FEQ simulates unsteady flow, the stagedischarge relation plots as a loop or series of loops, depending on the dynamic nature of the particular hydrograph. Because the loop is so narrow for this model scenario (approximately $0.5 \mathrm{ft}$ or less) the difference in the profiles resulting from the rising or falling limb of the hydrograph was less than the resolution of the LiDAR-derived DEM. The results demonstrate that the model is capable of simulating accurate water levels over a wide range of flows in the basin. More discussion of the accuracy of the simulated inundation surfaces can be found in the "Inundation Verification" section.

\section{Development of Water-Surface Profiles}

Profiles were developed for a total of 14 gage heights at 0.5 - $\mathrm{ft}$ intervals. The gage heights ranged between 11.0 $\mathrm{ft}$ and $17.5 \mathrm{ft}$ as referenced to the Salt Creek at Wood Dale streamgage (sta. no. 05531175). This range of gage heights includes below bankfull to almost the highest recorded gage height at the gage. A separate FEQ simulation was run for each mapped gage height at the streamgage with the input discharge required to generate the correct gage height determined by trial and error. 


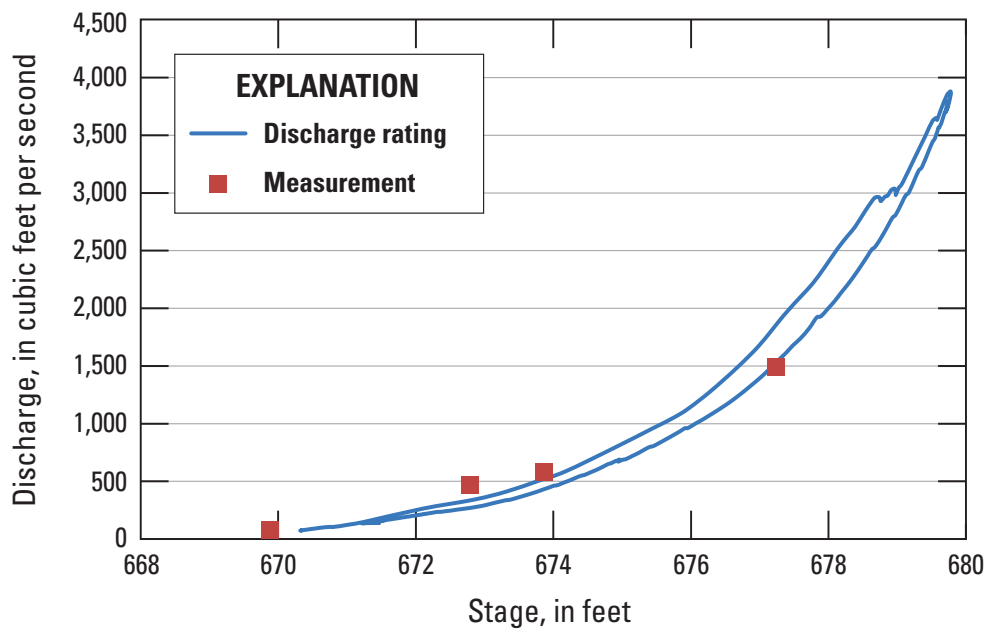

Figure 2. Graph showing stage-discharge relation generated by the FEO model for the September 2008 flood with historical discrete discharge measurements taken at the Salt Creek at Wood Dale streamgage. The modeled reach extended from upstream of the Chicago, Milwaukee, St. Paul \& Pacific Railroad to Interstate 290.

\section{Inundation Mapping}

Flood-inundation maps were developed for the 14 watersurface profiles generated for the gage heights observed at the Salt Creek at Wood Dale gage. The maps were created in an ArcMap (Ormsby and others, 2010) GIS by combining the water-surface profiles and DEM data. Estimated flood-inundation boundaries for each simulated profile were created by using a DEM with a 5-foot cell size, modeled cross sections, and water-surface elevations for specific pre-defined gage heights for the cross sections derived from FEQ hydraulic model. Water-surface elevation values were joined to the corresponding cross section and a water-level surface for each pre-defined gage height was generated by using an Arc Macro Language (AML) (ESRI, 1999a) script modified from an AML provided by the Illinois Department of Natural Resources (Rick Gosch, Illinois Department of Natural Resources, written commun., 2009). The inundation surface was then created by subtracting the ground-surface DEM from the water-level surface. The maps show estimated flood-inundated areas overlaid on high-resolution, georeferenced, aerial photographs of the study area for each of the water-surface profiles that were generated by the hydraulic model for every half foot change in gage height ranging from 11 to $17.5 \mathrm{ft}$.

\section{Inundation Verification}

High-water marks were collected by the USGS during the July 2010 flood. These high-water marks were compared to the extent of the inundation mapping. The peak gage height for the July 2010 flood at the Salt Creek at Wood Dale gage was $14.08 \mathrm{ft}$. This gage height corresponds to a water-surface elevation of $677.08 \mathrm{ft}$ (all elevations referenced to NAVD88). The high-water marks range in elevation from 669.2 to $676.8 \mathrm{ft}$. Excluding the 669.2 high-water mark because it appears to inaccurately portray the elevation of the high-water, the range is from 675.3 to $676.8 \mathrm{ft}$ (fig. 3). The two high-water marks collected closest to the gage (elevations of 676.7 and $676.8 \mathrm{ft}$ ) are most similar to the elevation of the water-surface peak at the gage $(677.08 \mathrm{ft})$. A number of the high-water marks were collected near the bend of the creek where the model may be less able to capture the complexity of the flow. It should also be noted that the simulated water-surface profile drops approximately 2.2 feet between Irving Park Road and Elizabeth Drive, so the water-surface elevation would be lower in the southern part of the reach than it is near the gage.

Eight of the nine high-water marks are within the mapped area for the $14 \mathrm{ft}$ gage height. One observed high-water mark, at a water-surface elevation of $675.5 \mathrm{ft}$, is located approximately 20 feet beyond the inundation surface boundary for the $14 \mathrm{ft}$ gage height and approximately $10 \mathrm{ft}$ beyond the inundation surface boundary for the $14.5 \mathrm{ft}$ gage height (note that the cell size of the mapping DEM is 5 feet). This high-water mark was measured on the Forest Preserve Path near a structure crossing Salt Creek. It appears that this path was not included in the topographic data and is likely at a lower elevation than is represented in the mapping DEM, which could explain the discrepancy in elevation between the inundation surface and the observed high-water mark.

The high-water marks help to verify the accuracy of the inundation surface. All the high-water marks collected were below the peak elevation measured at the gage and all but one was within the inundation boundary predicted by the model. 


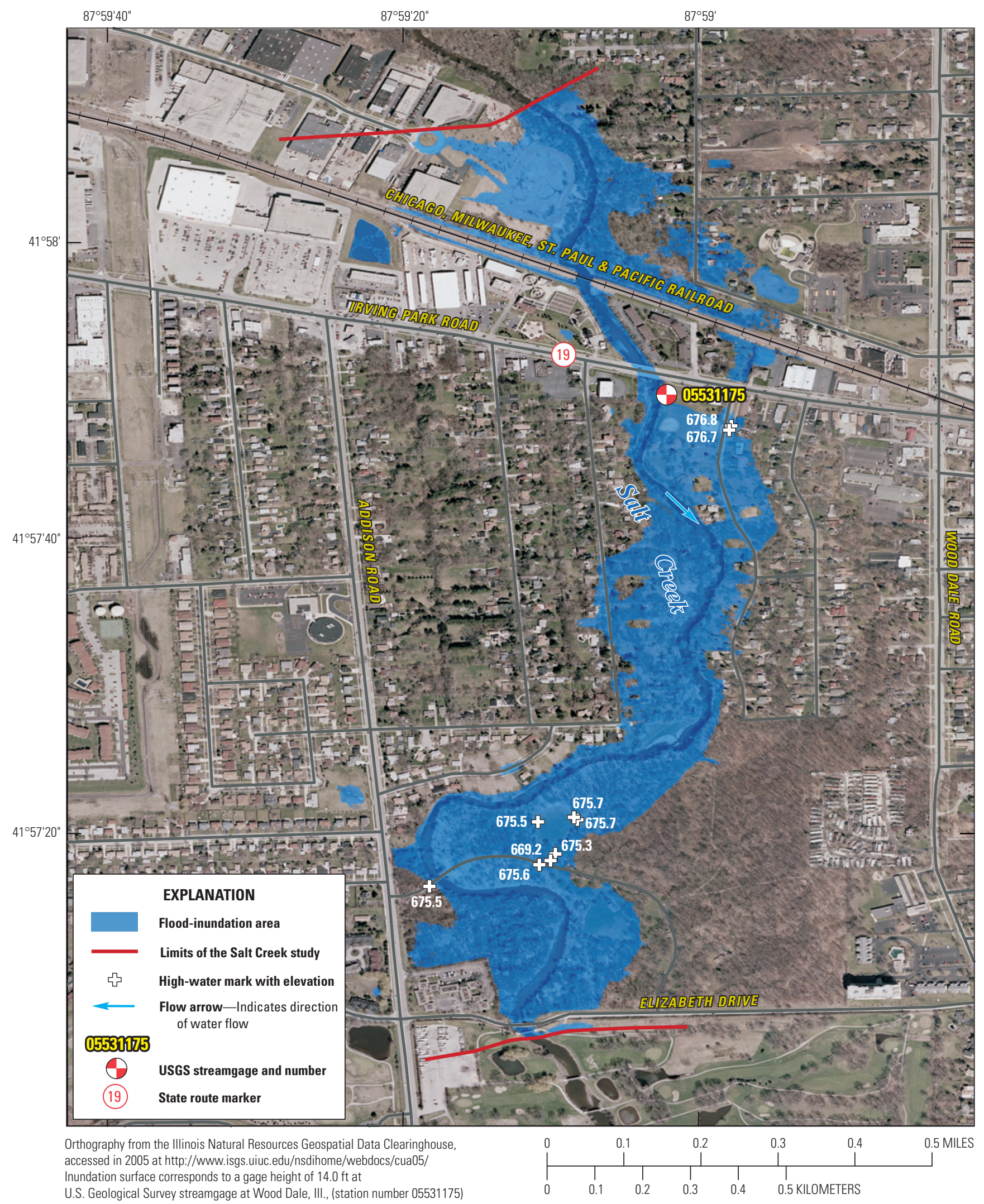

Figure 3. Map showing high-water marks from the July 2010 flood plotted with the inundation surface for the 14-ft gage height (677 feet NAVD88) at the Salt Creek at Wood Dale streamgage. 


\section{Salt Creek, Illinois Flood-Inundation Maps on the Internet}

A USGS Flood Inundation Mapping Science World Wide Web portal has been established at URL http://water.usgs.gov/ osw/flood_inundation/ to provide estimated flood-inundation information to the public. The maps from this study showing the extent of inundated areas can be downloaded in three electronic file formats from that portal: (1) GIS shapefile format (2) KMZ file format, and (3) Portable Document Format (PDF). Users can print out formatted maps or create customized maps by using available GIS data layers. The estimated flood-inundation maps are displayed in sufficient detail to note the extent of flooding with respect to individual structures so that preparations for flooding and decisions for emergency response can be performed efficiently.

\section{Uncertainty Associated with Inundation Maps}

Although the flood-inundation maps represent the boundaries of inundated areas with a distinct line, some uncertainty is associated with these maps. The flood boundaries shown were estimated based on gage heights (water-surface elevations) and streamflows at a selected USGS streamgage. Watersurface elevations along the stream reaches were estimated by hydraulic modeling, assuming unobstructed flow, and using gage height and hydrologic conditions anticipated at the USGS streamgage. The hydraulic model reflects the land-cover characteristics and any bridge, dam, levee, or other hydraulic structures existing in 2010. Unique meteorological factors (timing and distribution of precipitation) may cause actual streamflows along the modeled reach to vary from those assumed during a flood, which may lead to deviations in the water-surface elevations and inundation boundaries shown. Additional areas may be flooded due to unanticipated conditions such as: changes in the streambed elevation or roughness, backwater into major tributaries along a main stem river, or backwater from localized debris or ice jams. The accuracy of the floodwater extent portrayed on these maps will vary with the accuracy of the digital elevation model used to simulate the land surface.
Inundated areas shown should not be used for navigation, regulatory, permitting, or other legal purposes. Although USGS intends to make this server available 24 hours a day, 7 days a week, timely delivery of data and products from this server through the Internet is not guaranteed. The USGS provides these maps "as-is" for a quick reference, emergency planning tool but assumes no legal liability or responsibility resulting from the use of this information.

\section{Acknowledgments}

The authors wish to thank the many local, State, and Federal agencies that provided funding and cooperated in the operation and maintenance of the gage used for this study, especially John McLaughlin and other staff at the DuPage County Stormwater Management Division.

\section{Summary}

A series of estimated flood-inundation maps were developed in cooperation with the DuPage County Department of Economic Development \& Planning for Salt Creek between upstream of the Chicago, Milwaukee, St. Paul \& Pacific Railroad and Elizabeth Drive in Wood Dale, Illinois. These maps, available at URL (http://water.usgs.gov/osw/flood inundation/), in conjunction with the real-time gage height data from the USGS streamgage at Salt Creek at Wood Dale, Ill. (sta. no. 05531175), can help to guide the public in taking individual safety precautions and can provide city officials with a tool to efficiently manage emergency flood operations and flood mitigation efforts.

The maps were developed by using the FEQ and ArcMap programs to compute water-surface profiles and to delineate estimated flood-inundation areas for selected gage heights. The maps show estimated flood-inundation areas overlaid on high-resolution, georeferenced, aerial photographs of the study area for stream gage heights between $11.0 \mathrm{ft}$ and $17.5 \mathrm{ft}$ at the Salt Creek at Wood Dale streamgage. 


\section{References Cited}

Christopher B. Burke Engineering, Ltd., 2010, Floodplain Mapping Report and Documentation for Lower Salt Creek Watershed, Prepared for DuPage County Department of Engineering Division of Stormwater and Environmental Concerns. CBBEL project no. 09-0101.00001.

DuPage County Department of Economic Development and Planning, Division of Stormwater Management, 2011, Stormwater Management: accessed on January 31, 2011 at URL http://ec.dupageco.org/dec/saltcreek.htm

Environmental Systems Research Institute (ESRI), 1999a, ARC Macro Language-Self-study workbook, Developing ARC/INFO menus and macros with AML: Redlands, Calif., ESRI Press, 828 p. ISBN 978-1879102187

Environmental Systems Research Institute (ESRI), 1999b, Understanding GIS - The ARC/INFO method: Redlands, Calif., ESRI Press, Inc., 602 p, ISBN 978-1879102019

Federal Emergency Management Agency (FEMA), 2004, Flood Insurance Study, A Report of Flood Hazards in DuPage County, Illinois and Incorporated Areas: Flood Insurance Study Number 17043CV002A, variously paginated.

Franz, D.D., and Melching, C.S., 1997a, Full Equations (FEQ) model for the solution of the full, dynamic equations of motion for one-dimensional unsteady flow in open channels and through control structures: U.S. Geological Survey Water-Resources Investigations Report 96-4240, 258 p.
Franz, D.D., and Melching, C.S., 1997b, Full Equations Utility (FEQUTL) model for the approximation of hydraulic characteristics of open channels and control structures during unsteady flow: U.S. Geological Survey Water-Resources Investigations Report, 97-4037, 205 p.

Ormsby, Tim, Napoleon, E.J., Burke, Robert, Groessel, Carolyn, and Bowden, Laura, 2010, Getting to Know ArcGIS Desktop: Redlands, Calif., ESRI Press, 604 p., ISBN: 9781589482609

Price, T., 2011, Meteorologic Database Extension and Verification of HSPF Model for Salt Creek Watershed. Prepared for DuPage County Development and Environmental Concerns.

Shearman, J.O., 1990, User's manual for WSPRO-A computer model for water surface profile computations: Washington, D.C., U.S. Department of Transportation, U.S. Federal Highway Administration report no. FHWA-IP-89-027, $177 \mathrm{p}$.

U.S. Census Bureau, 2011, DuPage County QuickFacts: accessed on Jan. 26, 2011 at http://quickfacts.census.gov/ qfd/states/17/17043.html.

U.S. Geological Survey, 2011, National Water Information System-Web Interface, USGS 05531175 Salt Creek at Wood Dale, IL: U.S. Geological Survey, Water Resources, accessed on June 6, 2011 at http://waterdata. usgs.gov/il/nwis/inventory/?site_no $=05531175 \&$ agency $c d=U S G S \&$ amp.

Publishing support provided by:

Denver Publishing Service Center

Manuscript approved for publication Oct. 12, 2011

For more information concerning this publication, contact:

Director, Illinois Water Science Center

U.S. Geological Survey

1201 W. University Avenue, Suite 100

Urbana, IL 61801

Or visit the Illinois Water Science Center Web site at:

http://il.water.usgs.gov

This report is available at: $h t t p: / / p u b s . u s g s . g o v / s i m / 3185$ 
题 